\title{
PENERAPAN MEDIA GAMBAR PERISTIWA UNTUK MENINGKATKAN KEMAMPUAN MENULIS TEKS EKSPLANASI FENOMENA SOSIAL
}

\author{
Sarles Pandiangan \\ Sekolah Menengah Kejuruan Negeri 1 Sidikalang \\ sarlespandiangan57@gmail.com
}

\begin{abstract}
Abstrak: Tujuan penelitian ini adalah Penerapan Media Gambar Peristiwa Untuk Meningkatkan Kemampuan Menulis Teks Eksplanasi Fenomena Sosial pada Siswa. Penelitian ini dilaksanakan di SMK Negeri 1 Sidikalang pada siswa kelas XI TKJ 2 T.P. 2017/2018 dengan metode Penelitian Tindakan Kelas (Action Research). Subjek penelitian ini adalah siswa kelas XI TKJ 2 yang berjumlah 36 orang. Hasil penelitian diperoleh: (1) Perubahan sikap dan minat siswa dalam pembelajaran teks eksplanasi menunjukkan adanya perubahan semakin positif. Pada pra siklus siswa yang siap menerima pembelajaran baru mencapai 47,22\% dengan kategori kurang, pada siklus I meningkat menjadi $61,1 \%$ dan pada siklus II menjadi 80,56\% kategori baik. Sedangkan keaktifkan siswa pra siklus hanya mencapai 47,22\% siswa terlihat aktif dalam pembelajaran menulis teks eksplanasi, meningkat menjadi lebih baik menjadi 77,78\% kategori baik pada siklus I, dan pada siklus II jumlah siswa yang aktif meningkat menjadi 86,11\% kategori baik. (2) Peningkatan kemampuan menulis teks eksplanasi fenomena sosial menggunakan media gambar peristiwa mengalami peningkatan. Pada tes awal rata-rata yang dicapai adalah 71,56 dengan ketuntasan 25,0\%. Pada siklus I rata-rata kemampuan menulis teks eksplanasi mencapai 75,47 dengan ketuntasan 58,33\%. Pada siklus II rata-rata kemampuan menulis teks eksplanasi meningkat menjadi 78,56 dengan ketuntasan 80,56\%. (3) Adanya perbedaan kemampuan menulis teks eksplanasi fenomena sosial menggunakan media gambar peristiwa siswa yang signifikan dan positif antar siklus.
\end{abstract}

Kata Kunci: media gambar, kemampuan menulis, teks eksplanasi, fenomena sosial.

\begin{abstract}
The purpose of this study is the Application of Event Image Media to Improve the Capability of Writing Phenomenon of Explanation of Social Phenomena in Students. This research was carried out at Vocational High School Negeri 1 Sidikalang in class XI TKJ 2 T.P. 2017/2018 with the Action Research method. The subjects of this study were 36 students of class XI TKJ 2. The results were obtained: (1) Changes in students' attitudes and interests in learning explanatory texts showed that there were increasingly positive changes. In pre-cycle students who were ready to receive new learning reached $47.22 \%$ with less categories, in the first cycle increased to $61.1 \%$ and in the second cycle to $80.56 \%$ the good category. Whereas the activeness of pre-cycle students only reached $47.22 \%$ of students seen actively in learning to write explanatory texts, increasing to be better to $77.78 \%$ both categories in the first cycle, and in the second cycle the number of active students increased to $86.11 \%$ categories good. (2) Increasing the ability to write explanatory texts of social phenomena using the media picture of events has increased. In the initial test the average achieved was 71.56 with completeness of $25.0 \%$. In the first cycle, the average ability to write explanatory texts reached 75.47 with $58.33 \%$ completeness. In the second cycle the average ability to write explanatory texts increased to 78.56 with $80.56 \%$ completeness. (3) There is a difference in the ability to write explanatory text on social phenomena using media images of significant and positive student events between cycles.
\end{abstract}

Keywords: image media, writing ability, explanatory text, social phenomena.

\section{PENDAHULUAN}

Suatu proses belajar mengajar dikatakan baik apabila proses tersebut dapat membangkitkan kegiatan belajar mengajar yang efektif agar siswa secara aktif dapat mengembangkan potensi dirinya untuk memiliki kepribadian, kecerdasan dan keterampilan yang diperlukan dirinya dan masyarakat sehingga dapat meningkatkan hasil belajar yang maksimal. Pembelajaran bahasa dan sastra Indonesia pada hakikatnya berorientasi pada pembelajaran bahasa, mempelajari bahasa untuk belajar berkomunikasi dan mempelajari sastra untuk mengetahui nilai-nilai yang terkandung dalam karya sastra sehingga dapat belajar untuk menghargai manusia dan kemanusiannya. Adanya pembelajaran bahasa dan sastra Indonesia diharapkan dapat meningkatkan kemampuan dalam berkomunikasi, baik secara lisan maupun tulis serta dapat memberikan apresiasi terhadap hasil karya sastra. 
Pada kemampuan menyusun teks eksplanasi, pembelajaran lebih mengarah pada esensi dari teks ekplanasi atau bagaimana penyusunan struktur teks yang benar, dan peserta didik kerap kali mengalami kesulitan membedakan isi teks ekplanasi dengan teks lain. Salah satu jenis media yang dapat digunakan untuk pembelajaran bahsa Indonesia adalah media gambar. Media gambar sesuai kelompoknya merupakan media visual dua dimensi pada bidang tidak transparan.

Menurut Arsyad (2011: 15) media gambar termasuk dalam bentuk visual berupa gambar representasi seperti gambar, lukisan, atau foto yang menunjukkan bagaimana tampaknya suatu benda. Penyajian materi pelajaran dengan menggunakan gambar, tentu merupakan daya tarik tersendiri bagi pembelajar. Maka penggunaan gambar harus sesuai dengan materi pelajaran yang diajarkan, dan tujuan yang diinginkan. Penggunaan gambar khususnya gambar peristiwa fenomena sosial diharapkan dapat meningkatkan kemampuan siswa menulis teks eksplanasi.

Penelitian ini bertujuan untuk: (1) Untuk mengetahui perubahan perilaku belajar siswa kelas XI SMK Negeri 1 Sidikalang tahun ajaran 2016/2017 setelah mengikuti pembelajaran menulis teks eksplanasi fenomena sosial menggunakan media gambar peristiwa, (2) Untuk mengetahui peningkatan kemampuan menulis teks eksplanasi fenomana soaial menggunakan media gambar peristiwa siswa kelas XI SMK Negeri 1 Sidikalang tahun ajaran 2017/2018, dan (3) Untuk mengetahui adanya perbedaan kemampuan menulis teks eksplanasi fenomena sosial menggunakan media gambar peristiwa siswa yang signifikan dan positif antar siklus siswa kelas XI TKJ 2 SMK Negeri 1 Sidikalang tahun ajaran 2017/2018.

\section{Pengertian teks eksplanasi}

Teks eksplanasi merupakan salah satu jenis teks yang terdapat dalam Kurikulum 2013. Jenis teks eksplanasi diungkapkan Knapp dan Watkins dalam Yulianti (2015:26) sebagai salah satu jenis teks yang mengungkapkan urutan kejadian yang logis berkaitan dengan fungsi lingkungan sebagaimana memahami dan menginterpretasi bagaimana ide-ide dan konsep-konsep kebudayaan berlaku terdapat dua orientasi yang dikemukakan Knapp dan Watkins di dalam teks eksplanasi. Kedua orientasi tersebut, yaitu untuk menjelaskan jawaban atas pertanyaan "mengapa dan bagaimana". Selanjutnya, Pardiyono dalam Yulianti (2015: 26) mengungkapkan bahwa teks eksplanasi menjelaskan tentang proses terjadinya atau terbentuknya suatu fenomena alam atau sosial. Sependapat dengan Pardiyono, Isnatun dan Umi Farida (2014: 78) mengungkapkan hal yang sama mengenai definisi teks eksplanasi. Selain itu, keduanya menyebutkan bahwa paragraf dalam teks eksplanasi harus menjelaskan rangkaian penjelasan yang memberi jawaban terhadap judul. Pada umumnya, teks eksplanasi berkaitan erat dengan peristiwa alam dan sosial yang terjadi di lingkungan sekitar siswa (Kementerian Pendidikan dan Kebudayaan, 2013: iv-v).

\section{Penilaian Kemampuan Menulis Teks Ekplanasi}

Pengertian penilaian telah sering disampaikan oleh para ahli. Salah satu ahli pembelajaran yaitu Arifin (2009: 4-5) menyatakan : "Penilaian adalah suatu proses atau kegiatan yang sistematis dan berkesinambungan untuk mengumpulkan informasi tentang proses dan hasil belajar peserta didik dalam rangka membuat keputusan-keputusan berdasarkan kriteria dan pertimbangan tertentu. Hasil penilaian dapat memberikan informasi kepada guru untuk meningkatkan kemampuan mengajarnya dan membantu peserta didik mencapai perkembangan belajar secara optimal".

Terdapat beberapa model teknik penilaian untuk Kemampuan menulis yang memungkinkan penilai memperkecil kadar subjektivitas dirinya. Misalnya, penilaian holistik (holistic rubric) dan penilaian analitik (analytic rubric). Penilaian holistik merupakan penilaian yang tidak memperinci komponen atau kriteria penilaian, tetapi semuanya menjadi kesatuan. Selain itu, penilaian holistik dapat mempergunakan penilaian verbal seperti sangat baik, baik, dan cukup sehingga penilaian yang diberikan bersifat global. Selanjutnya, penilaian analitis adalah penilaian hasil tulisan siswa berdasarkan kualitas komponen-komponen pendukungnya. Dalam kegiatan menulis ada beberapa komponen atau aspek yang perlu diperhatikan, meliputi aspek isi, organisasi, kosakata, penggunaan bahasa, dan mekanik (Nurgiyantoro, 2012: 443-444).

\section{Media Gambar}

Gambar adalah media yang paling 
umum dipakai. Menurut Arsyad (2011) media gambar termasuk dalam bentuk visual berupa gambar representasi seperti gambar, lukisan, atau foto yang menunjukkan bagaimana tampaknya suatu benda. Menurut Sadiman, dkk (2011: 28-29), media grafis visual sebagimana halnya media yang lain. Media grafis untuk menyalurkan pesan dari sumber kepenerima pesan. Saluran yang dipakai menyangkut indera penglihatan. Pesan yang akan disampikan dituangkan ke dalam simbol-simbol komunikasi visual. Simbol-simbol tersebut perlu dipahami benar artinya agar proses penyampian pesan dapat berhasil dan efisien.

Menurut Arif S, et al (2011) gambar yang baik pada lazimnya dapat menggunakan kriteria-kriteria antara lain: (1) keaslian gambar, gambar menunjukkan situasi yang sebenarnya seperti melihat keadaan benda sesungguhnya; (2) kesederhanaan, sederhana dalam warna menimbulkan kesan tertentu yang mempunyai nilai estetis secara murni dan mengandung nilai praktis; (3) bentuk item, mudah dipahami dapat digunakan pada gambar dari majalah, surat kabar, dsb; (4) perbuatan menunjukkan hal yang sedang melakukan suatu perbuatan; (5) fotografi, gambar tidak terlalu terang/gelap asal dapat menarik dan efektif dalam pengajaran; dan (6) artistik, gambar disesuaikan dengan tujuan yang hendak dicapai.

Berdasarkan pendapatan tersebut bahwa dalam pemilihan media gambar perlu memperhatikan faktor-faktor meliputi keaslian gambar, kesederhanaan, bentuk item, perbuatan, fotografi, dan artistik.

Berdasarkan hasil penelitian terdahulu yang relevan dengan judul ini adalah penelitian yang dilakukan Herlinda (2013) mengkaji "Penggunaan Media Gambar Pemandangan dalam Pembelajaran Menulis Puisi. Hasil observasi prasiklus, 13 siswa atau $40 \%$ yang berantusias mengikuti pembelajaran menulis. Pada siklus I peran aktif siswa sudah meningkat, 16 siswa atau 50\% sudah mulai berantusias mengikuti pembelajaran. Sementara itu, siklus II $100 \%$ siswa sudah mulai berantusias mengikuti pembelajaran dengan baik; (3) Pembelajaran menulis puisi melalui media gambar pemandangan alam dapat meningkatkan kemampuan menulis puisi siswa.

Aisyah (2013) yang mengkaji Upaya Peningkatan Keterampilan Menulis Paragraf Deskripsi Berbahasa Jawa dengan Media Gambar pada Siswa Kelas XI TKR. D SMK Muhammadiyah Kutowinangun Kebumen
Tahun Ajaran 2012/ 2013". Subjek penelitian adalah siswa kelas XI TKR. Hasil penelitian menunjukkan rata-rata keterampilan menulis paragraf deskripsi berbahasa jawa dengan media gambar pada Siswa Kelas XI TKR mengalami peningkatan dari 56,71 pada prasiklus menjadi 70,91 pada siklus I. Kemudian meningkat lagi menjadi 78,21 pada siklus II. Siswa yang tuntas belajar pada prasiklus $10,52 \%$, siklus I $54,05 \%$ dan siklus II $92,10 \%$.

Hasil penelitian Eka Sari Mantiq (2017) dalam penelitiannya yang berjudul Peningkatan Kemampuan Menulis Teks Eksplanasi Fenomena Sosial Menggunakan Media Gambar. Hasil penelitian ini adalah (1) Berdasarkan gambar siswa mengamati secara fatkual, prosedural, berdasarkan gambar yang diamati siswa mampu mengembangkan teks ekplanasi. (2) Pengaruh media gambar peristiwa terhadap sikap dan minat siswa dalam pembelajaran teks eksplanasi dari prasiklus, Siklus I dan Siklus II menunjukkan adanya perubahan semakin positif.

Berdasarkan uraian tersebut, perlu dilakukan penelitian Penerapan Media Gambar Peristiwa Untuk Meningkatkan Kemampuan Menulis Teks Eksplanasi Fenomena Sosial pada Siswa Kelas XI TKJ 2 SMK Negeri 1 Sidikalang Tahun Pelajaran 2017/2018.

\section{METODE PENELITIAN}

Jenis penelitian yang dilakukan adalah jenis penelitian tindakan kelas (classroom action research). Penelitian ini dilaksanakan dalam dua siklus dengan melalui penerapan media gambar peristiwa di SMK Negeri 1 Sidikalang Tahun Pembelajaran 2017/2018. Subjek penelitian ini adalah siswa kelas XI TKJ 2 SMK Negeri 1 Sidikalang yang terdiri dari 36 orang siswa.

Objek penelitian ini adalah penerapan media gambar peristiwa untuk meningkatkan kemampuan menulis teks eksplanasi fenomena sosial pada siswa kelas XI TKJ 2 SMK Negeri 1 Sidikalang Tahun Pembelajaran 2017/2018.

\section{Desain Penelitian}

Jenis penelitian ini adalah penelitian tindakan kelas (Classroom Action Research) yang dilaksanakan dalam dua siklus. Desain penelitian yang dilaksanakan menggunakan model siklus Kemmis dan Mc Taggart. Setiap Siklus meliputi 4 tahap tiap siklusnya sebagai berikut: (1) Perencanaan Tindakan, 
Pelaksanaan Tindakan, (3) Observasi, dan (4) Refleksi dan Evaluasi (Arikunto, dkk 2009:16). Dimana Informasi dari siklus pertama sangat menentukan siklus berikutnya. Pada setiap akhir pembelajaran akan dilakukan evaluasi untuk memperoleh data hasil belajar siswa dan perubahan aktivitas siswa.

Pelaksanaan tindakan dilakukan sesuai dengan isi perencanaan yang telah disusun. Pelaksanaan tindakan pembelajaran ini terdiri atas dua siklus. yaitu pelaksanaan tindakan siklus I dan siklus II. Penjelasannya sebagai berikut:

Siklus I: Pelaksanaan tindakan siklus I ini melalui empat tahapan. Empat tahapan yang harus dilalui, yaitu perencanaan, pelaksanaan, pengamatan, dan refleksi.

a. Perencanaan Siklus I

1) Peneliti berdiskusi dengan sesama mengenai permasalahan yang muncul dalam pembelajaran menulis teks eksplanasi.

2) Peneliti menyusun stategi untuk memecahkan masalah dalam pembelajaran menulis teks eksplanasi.

3) Peneliti membuat rencana pelaksanaan pembelajaran (RPP) tentang menulis teks eksplanasi menggunakan media gambar peristiwa fenomana sosial.

4) Peneliti menyusun dan mempersiapkan mempersiapkan instrumen penelitian berupa angket, lembar observasi, tes tertulis, dan dokumentasi kegiatan pembelajaran menulis teks eksplanasi menggunakan media gambar peristiwa fenomena sosial.

5) Menentukan pedoman penilaian dalam pembelajaran menulis teks eksplanasi.

b. Pelaksanaan Tindakan Siklus I

Tindakan yang dilakukan pada siklus I sesuai dengan penerapan isi perencanaan yang telah disusun yaitu:

1) Pendahuluan

Guru memberikan motivasi dan penjelasan mengenai manfaat serta tujuan yang diperoleh setelah mengikuti kegiatan pembelajaran menulis teks eksplanasi, agar siswa tertarik dalam kegiatan tersebut.

2) Kegiatan Inti

Pada kegiatan ini guru menjelaskan materi tentang teks eksplanasi yang meliputi pengertian, struktur organisasi teks eksplanasi dan memberikan contoh menyusun teks eksplanasi dengan meggunakan media gambar.

3) Penutup

Guru menyimpulkan hasil pembelajaran dan memberikan motivasi kepada siswa agar siswa rajin berlatih membuat teks eksplanasi.

c. Pengamatan Siklus I

Pengamatan dilakukan terhadap proses pembelajaran dan hasil menulis teks eksplanasi dengan menggunakan media gambar peristiwa fenomena sosial. Segala aktivitas yang terjadi di kelas dicatat dalam catatan lapangan sebagai bukti telah dilaksanakannya pembelajaran.

d. Refleksi Siklus I

Refleksi ini bertujuan untuk mengevaluasi tindakan yang telah dilakukan dengan cara melakukan penilaian proses dan masalah yang muncul. Jika nilai siswa pada siklus I belum mengalami peningkatan, maka dilanjutkan pada siklus II.

Siklus II: Siklus II merupakan kelanjutan usaha dari siklus I untuk meningkatkan kemampuan menulis teks eksplanasi. Tahap pelaksanaan pembelajaran siklus II juga melalui empat langkah yaitu.

a. Perencanaan Siklus II

Pada tahap ini guru peneliti memperbaiki rencana pelaksanaan pembelajaran (RPP), memperbaiki lembar pengamatan, menyiapkan angket untuk siswa, dan dokumentasi yang berupa foto.

b. Pelaksanaan Tindakan Siklus II

Pembelajaran siklus II merupakan perbaikan dari siklus I. Berdasarkan rencana yang telah disusun, tindakan selanjutnya adalah pelaksanaan siklus II.

1) Pendahuluan

Guru menanyakan kesulitan-kesulitan yang dihadapi siswa dalam menulis teks eksplanasi, kemudian siswa diberi arahan dan bimbingan agar dalam pelaksanaan kegiatan menulis eksplanasi pada siklus II lebih baik.

2) Kegiatan Inti

Pada kegiatan ini guru menjelaskan materi tentang teks eksplanasi yang meliputi pengertian teks eksplanasi, struktur teks eksplanasi dan memberikan 
contoh menyusun teks eksplanasi dengan meggunakan media gambar.

3) Penutup

Guru menyimpulkan hasil pembelajaran dan memberikan motivasi kepada siswa agar siswa rajin berlatih menulis teks eksplanasi.

4) Pengamatan Siklus II

Pada siklus II peneliti menggunakan lembar pengamatan dan melakukan pemotretan selama proses belajar mengajar. Peneliti juga membagikan angket kepada siswa untuk mengetahui tanggapan, kesan, dan pesan siswa selama mengikuti pembelajaran menulis teks eksplanasi fenomena sosial dengan bantuan media gambar peristiwa.

c. Refleksi Siklus II

1) Instrumen Penelitian

Arikunto (2013: 160) berpendapat bahwa instrumen penelitian adalah alat atau fasilitas yang digunakan oleh peneliti dalam mengumpulkan data agar pekerjaannya lebih mudah dan hasilnya lebih baik, dalam arti lebih cermat, lengkap, sistematis sehingga lebih mudah diolah. Instrumen yang digunakan dalam penelitian ini berbentuk tes dan nontes.

2) Instrumen Tes

Aspek yang dinilai dalam pembuatan teks eksplanasi adalah isi, organisasi, kosakata, penggunaan bahasan dan mekanik.

Pedoman penskoran menulis teks eksplanasi terdapat pada tabel berikut ini:

Tabel 1. Kisi-kisi Penilaian Teks Eksplanasi

\begin{tabular}{|c|l|c|}
\hline No & \multicolumn{1}{|c|}{ Aspek yang Dinilai } & Nilai \\
\hline 1 & Isi & $13-30$ \\
\hline 2 & Struktur & $7-20$ \\
\hline 3 & Kosakata & $7-20$ \\
\hline 4 & Penggunaan bahasa & $7-20$ \\
\hline 5 & Mekanik & $2-10$ \\
\hline \multicolumn{2}{|l|}{ Skor maksimal } & 100 \\
\hline
\end{tabular}

Kategori Penilaian:

1. $86-100=$ Sangat Baik

2. $70-85=$ Baik

3. $56-69=$ Cukup

4. $0-55=$ Kurang

(Sukirno, 2013: 333)

3) Instrumen Nontes

Nurgiantoro (2012: 90) berpendapat bahwa instrumen nontes merupakan alat penilaian yang digunakan untuk mendapatkan informasi tentang keadaan peserta didik atau peserta tes dengan alat tes. Bentuk instrumen nontes pada penelitian ini meliputi lembar pengamatan, catatan lapangan, angket, dan dokumentasi.

\section{Teknik Analisis Data}

Teknik Kuantitatif: Rumus nilai rata-rata hitung, yaitu sebagai berikut.

Keterangan:

$$
\bar{x} \quad=\frac{\sum x i}{N}
$$

$\bar{x} \quad=$ Rata-rata hitung nilai siswa

$\sum x i=$ Jumlah nilai siswa

$\mathrm{N} \quad=$ Jumlah siswa

(Arikunto, 2009)

Teknik Kualitatif: Teknik kualitatif ini diambil dari data pengamatan, angket dan catatan lapangan. Lembar pengamatan disajikan dalam bentuk tabel sesuai dengan aspek yang dinilai untuk siswa. Keberhasilan proses dapat dilihat dari peningkatan aktivitas siswa dalam kegiatan pembelajaran menulis teks eksplanasi fenomena sosial dengan media gambar peristiwa harus mencapai minimal $85 \%$ siswa memperoleh nilai 75 .

\section{HASIL DAN PEMBAHASAN \\ Hasil Penelitian \\ Deskripsi Hasil Penelitian}

Penelitian ini dilakukan pada siswa kelas XI TKJ 2 yang berjumlah 36 siswa.

Hasil Non-tes: Hasil Nontes pada siklus I meliputi hasil pengamatan dan angket. Berikut disajikan data hasil pengamatan dan angket pada siklus I dan II sebagai berikut:

Tabel 2. Pengamatan Aktivitas Siswa

\begin{tabular}{|c|c|c|c|c|c|c|c|c|c|}
\hline \multirow{3}{*}{$\begin{array}{l}\mathrm{N} \\
\mathrm{o}\end{array}$} & \multirow{3}{*}{ Indikator } & \multicolumn{4}{|c|}{ Siklus I } & \multicolumn{4}{|c|}{ Siklus II } \\
\hline & & \multicolumn{2}{|c|}{ Positif } & \multicolumn{2}{|c|}{ Negatif } & \multicolumn{2}{|c|}{ Positif } & \multicolumn{2}{|c|}{ Negatif } \\
\hline & & $\mathrm{F}$ & $\%$ & $\mathrm{~F}$ & $\%$ & $\mathrm{~F}$ & $\%$ & $\mathrm{~F}$ & $\%$ \\
\hline 1 & $\begin{array}{l}\text { Siswa siap dan menerima } \\
\text { pembelajaran }\end{array}$ & 22 & $\begin{array}{c}61,1 \\
1\end{array}$ & 14 & 38,89 & 29 & 80,56 & 7 & 19,44 \\
\hline
\end{tabular}




\begin{tabular}{|l|l|c|c|c|c|c|c|c|c|}
\hline 2 & $\begin{array}{l}\text { Perhatian siswa terhadap } \\
\text { pembelajaran }\end{array}$ & 26 & $\begin{array}{c}72,2 \\
2\end{array}$ & 10 & 27,78 & 28 & 77,78 & 8 & 22,22 \\
\hline 3 & $\begin{array}{l}\text { Siswa tertarik dan memberi } \\
\text { kan tanggapan positif } \\
\text { terhadap media }\end{array}$ & 28 & $\begin{array}{c}77,7 \\
8\end{array}$ & 8 & 22,22 & 30 & 83,33 & 6 & 16,67 \\
\hline 4 & $\begin{array}{l}\text { Siswa aktif mengerjakan } \\
\text { tugas }\end{array}$ & 28 & $\begin{array}{c}77,7 \\
8\end{array}$ & 8 & 22,22 & 31 & 86,11 & 5 & 13,89 \\
\hline
\end{tabular}

Keterangan :

BS: Baik Sekali (siswa aktif > 85\%)

B : Baik (siswa aktif $75 \%-85 \%$ )

C : Cukup (siswa aktif $60 \%-74 \%$ )

$\mathrm{K}$ : Kurang (siswa aktif <60)

Hasil tersebut menunjukkan bahwa bila dibandingkan dengan siklus I seluruh aktivitas belajar siswa mengalami peningkatan dan mencapai nilai indikator keberhasilan yaitu $75 \%$ (baik).

Hasil Angket: Pengisian angket dilakukan setelah siswa mendapat pembelajaran menulis teks eksplanasi menggunakan media gambar peristiwa.

Tabel 3. Hasil Angket Tanggapan Siswa

\begin{tabular}{|c|c|c|c|c|c|c|c|c|c|}
\hline \multirow{3}{*}{$\begin{array}{l}\mathrm{N} \\
\mathrm{O}\end{array}$} & \multirow{3}{*}{ Pertanyaan } & \multicolumn{4}{|c|}{ Siklus I } & \multicolumn{4}{|c|}{ Siklus II } \\
\hline & & \multicolumn{2}{|c|}{ Ya } & \multicolumn{2}{|c|}{ Tidak } & \multicolumn{2}{|c|}{$\mathrm{Ya}$} & \multicolumn{2}{|c|}{ Tidak } \\
\hline & & $\mathrm{F}$ & $\%$ & $\mathrm{~F}$ & $\%$ & $\mathrm{~F}$ & $\%$ & $\mathrm{~F}$ & $\%$ \\
\hline 1 & $\begin{array}{l}\text { Sebelum mendapat materi } \\
\text { menulis teks eksplanasi } \\
\text { dengan media gambar } \\
\text { peristiwa, saya belum } \\
\text { mampu Menulis teks } \\
\text { eksplanasi }\end{array}$ & 26 & 61,14 & 10 & 38,89 & 3 & 8,33 & 33 & 91,67 \\
\hline 2 & $\begin{array}{l}\text { Setelah mendapat materi } \\
\text { menulis teks eksplanasi } \\
\text { dengan media gambar } \\
\text { peristiwa, saya semakin } \\
\text { mampu Menulis teks } \\
\text { eksplanasi }\end{array}$ & 25 & 69,44 & 11 & 30,56 & 29 & 80,56 & 7 & 19,44 \\
\hline 3 & $\begin{array}{l}\text { Media gambar peristiwa } \\
\text { peristiwa membantu saya } \\
\text { untuk menuangkan dan } \\
\text { mengembangkan ide saa } \\
\text { tmelakukan kegiatan } \\
\text { menulis } \\
\text { Teks eksplanasi }\end{array}$ & 26 & 72,22 & 10 & 27,78 & 30 & 83,33 & 6 & 16,67 \\
\hline 4 & $\begin{array}{l}\text { Setelah mendapat materi } \\
\text { menulis teks eksplana si } \\
\text { dengan media gambar } \\
\text { peristiwa, saya semakin } \\
\text { tertarik Menulis teks } \\
\text { eksplanasi }\end{array}$ & 27 & 75,00 & 9 & 25,00 & 29 & 80,56 & & 19,44 \\
\hline 5 & $\begin{array}{l}\text { Setelah mendapat materi } \\
\text { menulis teks eksplanasi } \\
\text { dengan media gambar } \\
\text { peristiwa, Sekarang saya } \\
\text { tahu cara menulis teks } \\
\text { eksplanasi dengan benar }\end{array}$ & 27 & 75,00 & 9 & 25,00 & 28 & 77,78 & 8 & 22,22 \\
\hline
\end{tabular}




\begin{tabular}{|c|c|c|c|c|c|c|c|c|c|}
\hline \multirow{3}{*}{$\begin{array}{l}\mathrm{N} \\
\mathrm{O}\end{array}$} & \multirow{3}{*}{ Pertanyaan } & \multicolumn{4}{|c|}{ Siklus I } & \multicolumn{4}{|c|}{ Siklus II } \\
\hline & & \multicolumn{2}{|c|}{$\mathrm{Ya}$} & \multicolumn{2}{|c|}{ Tidak } & \multicolumn{2}{|c|}{ Ya } & \multicolumn{2}{|c|}{ Tidak } \\
\hline & & $\mathrm{F}$ & $\%$ & $\mathrm{~F}$ & $\%$ & $\mathrm{~F}$ & $\%$ & $\mathrm{~F}$ & $\%$ \\
\hline 6 & $\begin{array}{l}\text { Pembelajaran materi } \\
\text { menulis teks eksplanasi } \\
\text { dengan media gambar } \\
\text { peristiwa menyenangkan }\end{array}$ & 28 & 77,78 & 8 & 22,22 & 32 & 88,89 & 4 & 11,11 \\
\hline
\end{tabular}

Berdasarkan hasil pada Tabel.3 menunjukkan siswa mengalami peningkatan pemahaman terhadap materi pembelajaran teks eksplanasi pada siklus II bila dibandingkan siklus I.

\section{Peningkatan Kemampuan Menulis Teks Eksplanasi}

Tabel 4. Skor Rata-rata Setiap Aspek dari Pra Siklus Sampai Siklus II

\begin{tabular}{|c|c|c|c|c|c|c|}
\hline \multirow[b]{2}{*}{$\begin{array}{l}\mathrm{N} \\
\mathrm{o}\end{array}$} & \multirow[b]{2}{*}{ Aspek } & \multicolumn{3}{|c|}{ Skor Rata-rata } & \multirow{2}{*}{$\begin{array}{c}\text { Peningkatan } \\
\text { Prasiklus ke } \\
\text { Siklus I }\end{array}$} & \multirow{2}{*}{$\begin{array}{c}\text { Peningkatan } \\
\text { Siklus I ke } \\
\text { Siklus II }\end{array}$} \\
\hline & & $\begin{array}{c}\text { Pra } \\
\text { Siklus }\end{array}$ & $\begin{array}{c}\text { Siklus } \\
\text { I }\end{array}$ & $\begin{array}{c}\text { Siklus } \\
\text { II }\end{array}$ & & \\
\hline 1 & Isi & 21,19 & 22,00 & 22,83 & 0,81 & 0,83 \\
\hline 2 & Organisasi & 14,06 & 14,67 & 15,44 & 0,61 & 0,77 \\
\hline 3 & Kosa Kata & 14,56 & 15,31 & 15,61 & 0,75 & 0,3 \\
\hline 4 & Penggunaan Bahasa & 14,69 & 15,53 & 15,78 & 0,83 & 0,25 \\
\hline 5 & Mekanik & 7,06 & 7,97 & 8,89 & 0,91 & 0,92 \\
\hline & Jumlah & 71,06 & 71,56 & 78,56 & 3,92 & 3,09 \\
\hline
\end{tabular}

Secara keseluruhan peningkatan dari pra siklus ke siklus I adalah 3,92 yaitu dari 71,06 menjadi 71,56. Peningkatan dari siklus I ke siklus II 3,09 yaitu dari 71,56 menjadi 78,56.

\section{Pembahasan Hasil Penelitian}

Peningkatan kemampuan menulis teks eksplanasi diikuti semakin meningkatkannya siswa yang mencapai KKM. Ketuntasan menulis teks eksplanasi dari tes awal sampai siklus II adalah sebagai berikut:

Tabel 5. Perbandingan Ketuntasan Siswa Pra Siklus, Siklus I dan Siklus II

\begin{tabular}{|c|c|c|c|}
\hline No & Tahap & $\begin{array}{c}\text { Jumlah } \\
\text { Siswa Yang } \\
\text { Tuntas }\end{array}$ & $\begin{array}{c}\text { Persentase } \\
(\%)\end{array}$ \\
\hline 1 & Prasiklus & 9 & 25 \\
\hline 2 & Siklus I & 21 & 58,33 \\
\hline 3 & Siklus II & 29 & 80,56 \\
\hline
\end{tabular}

Berdasarkan tabel tersebut, terlihat bahwa persentase ketuntasan hasil belajar siswa baru mencapai $25,0 \%$. Selanjutnya, pada siklus I siswa yang sudah mencapai ketuntasan hasil belajar 58,33\%. Pada siklus II sebanyak $80,56 \%$ sudah dinyatakan tuntas atau memenuhi syarat KKM. Pencapaian siklus II tersebut sudah memenuhi indicator keberhasilan penelitian yang telah ditetapkan, yakni ketuntasan belajar siswa lebih dari $75 \%$. Dengan demikian, penggunaan penggunaan media gambar peristiwa dapat meningkatkan kemampuan siswa menulis teks eksplanasi.

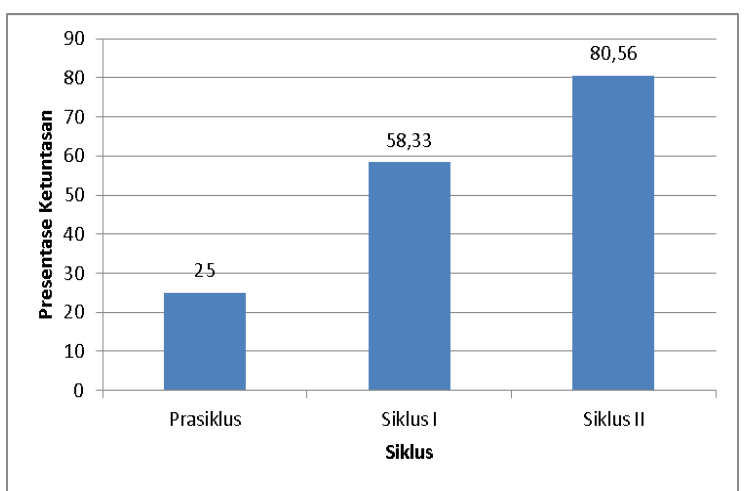

Gambar 1. Grafik Ketuntasan Belajar Prasiklus, Siklus I dan Siklus II

Skor aspek I pada prasiklus 24, siklus I 24 dan meningkat pada siklus II menjadi 27. Pada siklus I pada aspek organiasi ,kosa kata, penggunaan bahasa, dan mekanik tidak mengalami peningkatan. Namun pada siklus II seluruh aspek mengalami peningkatan sehingga mempengaruhi kenaikan yang cukup signifikan pada kemampuan menulis teks eksplanasi secara keseluruhan.

Hasil penelitian terhadap Penerapan media gambar peristiwa dapat menimbulkan 
perubahan sikap dan minat siswa dalam pembelajaran teks eksplanasi menunjukkan hal yang sama di dukung dalam penelitian Herlinda (2013) bahwa Penggunaan Media Gambar Pemandangan dalam Pembelajaran Menulis Puisi. Hasil observasi prasiklus, 13 siswa atau $40 \%$ yang berantusias mengikuti pembelajaran menulis. Pada siklus I peran aktif siswa sudah meningkat, 16 siswa atau 50\% sudah mulai berantusias mengikuti pembelajaran. Sementara itu, siklus II $100 \%$ siswa sudah mulai berantusias mengikuti pembelajaran dengan baik; (3) Pembelajaran menulis puisi melalui media gambar pemandangan alam dapat meningkatkan kemampuan menulis puisi siswa.

Penelitian lain yang dilakukan oleh Aisyah (2013) mengkaji tentang Upaya Peningkatan Keterampilan Menulis Paragraf Deskripsi Berbahasa Jawa dengan Media Gambar pada Siswa. Subjek penelitian adalah siswa kelas XI TKR. Hasil penelitian menunjukkan rata-rata keterampilan menulis paragraf deskripsi berbahasa jawa dengan media gambar pada Siswa Kelas XI TKR mengalami peningkatan dari 56,71 pada prasiklus menjadi 70,91 pada siklus I. Kemudian meningkat lagi menjadi 78,21 pada siklus II. Siswa yang tuntas belajar pada prasiklus $10,52 \%$, siklus I $54,05 \%$ dan siklus II $92,10 \%$.

Hal yang sama juga oleh penelitian Eka Sari Mantiq (2017) dalam penelitiannya yang berjudul Peningkatan Kemampuan Menulis Teks Eksplanasi Fenomena Sosial Menggunakan Media Gambar. Hasil penelitian ini adalah (1) Berdasarkan gambar siswa mengamati secara fatkual, prosedural, berdasarkan gambar yang diamati siswa mampu mengembangkan teks ekplanasi. (2) Pengaruh media gambar peristiwa terhadap sikap dan minat siswa dalam pembelajaran teks eksplanasi dari prasiklus, Siklus I dan Siklus II menunjukkan adanya perubahan semakin positif.

\section{PENUTUP}

Berdasarkan hasil penelitian dan pembahasan yang telah dilakukan, peneliti mengambil kesimpulan sebagai berikut: (1) Penerapan media gambar peristiwa dapat menimbulkan perubahan sikap dan minat siswa dalam pembelajaran teks eksplanasi. Pada pra siklus siswa yang siap menerima pembelajaran baru mencapai 47,22\% dengan kategori kurang, pada siklus I meningkat menjadi $61,1 \%$ dan pada siklus II menjadi $80,56 \%$ kategori baik. Sedangkan keaktifkan siswa pra siklus hanya mencapai $47,22 \%$ siswa terlihat aktif dalam pembelajaran menulis teks eksplanasi, meningkat menjadi lebih baik menjadi $77,78 \%$ kategori baik pada siklus I, dan pada siklus II jumlah siswa yang aktif meningkat menjadi $86,11 \%$ kategori baik. (2) Peningkatan kemampuan menulis teks eksplanasi fenomena sosial menggunakan media gambar peristiwa mengalami peningkatan. Peningkatan kemampuan menulis teks eksplanasi tersebut diikuti dengan semakin meningkatnya jumlah siswa yang mencapai KKM 75. Pada tes awal rata-rata yang dicapai adalah 71,56 dengan ketuntasan $25,0 \%$. Kemudian pada siklus I ratarata kemampuan menulis teks eksplanasi mencapai 75,47 dengan ketuntasan 58,33\%. Pada siklus II rata-rata kemampuan menulis teks eksplanasi meningkat menjadi 78,56 dengan ketuntasan $80,56 \%$. (3) Adanya perbedaan kemampuan menulis teks eksplanasi fenomena sosial menggunakan media gambar peristiwa siswa yang signifikan dan positif antar siklus siswa kelas XI TKJ 2 SMK Negeri 1 Sidikalang tahun ajaran 2017/2018.

\section{DAFTAR PUSTAKA}

Akhadiah, Sabarti, Maidar G. Arsyad, dan Sakura H. Ridwan. (1998). Pembinaan Kemampuan Menulis Bahasa Indonesia. Jakarta: Erlangga.

Aisyah, Nur. (2013). "Upaya Peningkatan Keterampilan Menulis Paragraf Deskripsi Berbahasa Jawa dengan Media Gambar pada Siswa Kelas XI TKR. D SMK Muhammadiyah Kutowinangun Kebumen Tahun Ajaran 2012/2013". Jurnal Program Studi Pendidikan Bahasa dan Sastra Jawa Universitas Muhammadiyah Purworejo, 02 (1), 2029.

Arikunto, dkk. (2009). Prosedur Penelitian. Jakarta: Bumi Aksara.

Arikunto, Suharsimi. (2013). Prosedur Penelitian: Suatu Pendekatan Praktik. Jakarta: PT Rineka Cipta.

Herlinda, Binan. (2013). "Penggunaan Media Gambar Pemandangan dalam Pembelajaran Menulis Puisi pada Siswa Kelas VIII SMP N 9 Purworejo Tahun Pelajaran 2013/2014. Skripsi. Universitas Muhammadiyah Purworejo.

Kementerian Pendidikan dan Kebudayaan. (2013). Bahasa Indonesia Wahana 
Pengetahuan untuk SMP/Mts Kelas VII: Buku Guru. Jakarta: Kementerian Pendidikan dan Kebudayaan.

Mantiq, Eka Sari. (2016). "Peningkatan Kemampuan Menulis Teks Eksplanasi Fenomena Sosial Menggunakan Media Gambar Peristiwa pada Siswa Kelas XI SMK Negeri 2 Kebumen Tahun Pelajaran 2016/2017. Skripsi. Universitas Muhammadiyah Purworejo.

Nurgiyantoro, Burhan. (2012). Penilaian Pembelajaran Bahasa Berbasis
Kompetensi. Yogyakarta: BPFE.

Sadiman, Arif S, dkk. (2011). Media Pendidikan, Pengertian, Pengembangan, dan Pemanfaatannya. Jakarta: PT. Grafindo Persada.

Yuliyanti. (2015). Diakses 8 Nopember 2017 "Efektivitas Strategi QUIP (questions into paragraphs) dalam Pembelajaran Menulis Teks Eksplanasi pada Siswa Kelas VII SMP N 1 Imogiri Bantul DIY". Skripsi. Diakses 8 Nopember 2017, dari http://digilib.unnes.ac.id 